\title{
1,1-Dibutoxybutane as a Petroleum Diesel Fuel Blending Component and Their Mixture Performance
}

\author{
Yoeswono $^{1}$, Iip Izul Falah ${ }^{2}$ and Triyono ${ }^{2}$ \\ 1. The Education and Training Center on Oil and Gas, Cepu 58315, Indonesia \\ 2. Department of Chemistry, Gadjah Mada University, Yogyakarta 55281, Indonesia
}

Received: September 05, 2016 / Accepted: September 18, 2016 / Published: December 31, 2016.

\begin{abstract}
Effect of 1,1-dibutoxybutane (DBB) addition on petroleum DF (diesel fuel) performance has been studied. The study was started by preparing DBB from decomposition of 1-butanol on manganese impregnated on activated carbon $(\mathrm{Mn} / \mathrm{AC})$ catalyst at $450{ }^{\circ} \mathrm{C}$ in stainless steel reactor. The product was distilled at $200{ }^{\circ} \mathrm{C}$ and the residue obtained was analyzed by GC-MS and HSQC NMR to confirm its structure and purity. The DBB-DF mixtures were prepared at different compositions and determined their excess molar volume, homogeneity, phase stability, ignition quality, lubricity, cold flow quality, energy content, and viscosity. The addition of DBB into DF formed a homogeneous mixture and had a good phase stability. The mixtures gave positive excess molar volume values over the whole concentration ranges. The ignition quality and lubricity of the mixtures increased without lost in cold flow quality. Slight decreased in viscosity and energy content per mass unit were observed.
\end{abstract}

Key words: 1,1-dibutoxybutane, petroleum diesel fuel, blending component, fuel mixture characteristics.

\section{Introduction}

Recently, petroleum oil depletion and environment quality degradation are becoming global issues. Several efforts have been made to minimize their effects and the use of renewable fuel is one of the alternative solutions which has a great attention to tackle those issues [1, 2]. Biodiesel is a renewable fuel which has been produced commercially. Its blend with petroleum DF (diesel fuel) has increased diesel engine performance and gave lower $\mathrm{HC}, \mathrm{CO}$ and particulate matter emissions [3]. But there are some barriers on the use of biodiesel. Higher pour point, lower oxidation stability, and higher $\mathrm{NO}_{\mathrm{x}}$ emission [4] limit its use as diesel fuel blending component.

Another potential oxygenated fuels are acetals. Some of them are suitable for diesel fuel additive because of their high cetane numbers $[5,6]$. Acetals addition into DF could reduce exhaust smoke [7, 8] and

Corresponding author: Yoeswono, Ph.D., research field: alternative energy.
$\mathrm{NO}_{\mathrm{x}}$ emission [7]. However, the minimum limit of flash point in DF specification allowed only higher acetals which are potential for practical use as DF blending component [8].

Acetals can be synthesized by reacting aldehydes with alcohols under conditions of acid catalysis $[8,9]$ and can be synthesized directly from primary alcohol $[10,11]$. Some type of acetals have been studied for their suitability as DF blending components, such as dimethoxyethane, dimethoxypropane [5], and 1,1,3-triethoxypropane [12]. However, reports on the use of 1,1-dibutoxybutane (DBB) as a DF blending component are still limited. DBB as a DF blending component is interesting to be studied because of its high cetane number [13] and can be derived directly from 1-butanol which produced from renewable resources such in $\mathrm{ABE}$ (acetone, butanol, ethanol) fermentation process [14]. The molecular structure of DBB is shown in Fig. 1.

In this report, suitability of DBB as a DF blending component has been explored by conducting some 


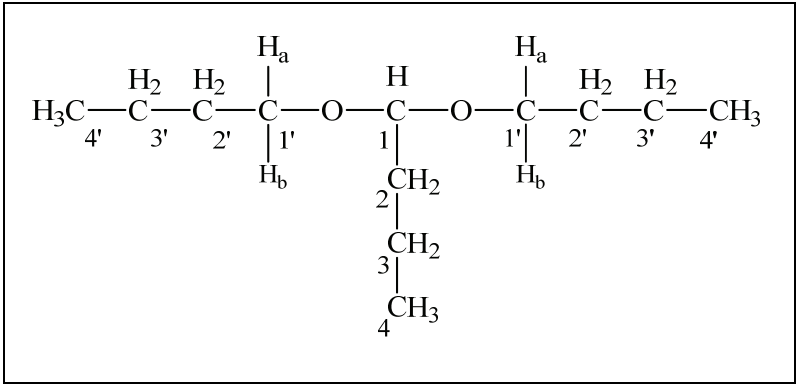

Fig. 1 The molecular structure of 1,1-dibutoxybutane.

characterizations of their mixtures, i.e., excess molar volume $\left(\bar{V}^{E}\right)$, homogeneity, phase stability, ignition quality, lubricity, cold flow quality, energy content, and viscosity.

\section{Experimental}

\subsection{Material and Methods}

Manganese dichloride tetrahydrate $\left(\mathrm{MnCl}_{2} \cdot 4 \mathrm{H}_{2} \mathrm{O}\right)$ and 1-butanol $\left(\mathrm{C}_{4} \mathrm{H}_{9} \mathrm{OH}\right)$ were purchased from Merck. Nitrogen $\left(\mathrm{N}_{2}\right)$ and hydrogen $\left(\mathrm{H}_{2}\right)$ gas were purchased from PT. Samator-Indonesia. The activated carbon was purchased from PT. Bayu Lestari-Indonesia. DF was obtained from the Education and Training Center on Oil and Gas Refinery—Cepu (Indonesia).

\subsection{General Procedure}

The Mn/AC catalyst was prepared by dry impregnation of $\mathrm{Mn}$ on activated carbon using $\mathrm{MnCl}_{2}$ solution as the Mn source in such a way to give $1 \%$ by weight of $\mathrm{Mn}$ on activated carbon. The catalyst was calcined at $450{ }^{\circ} \mathrm{C}$ for $4 \mathrm{~h}$ in $20 \mathrm{~mL} / \mathrm{min} \mathrm{N}_{2}$ and reduced at $300{ }^{\circ} \mathrm{C}$ for $3 \mathrm{~h}$ by $10 \% \mathrm{H}_{2}$ in $\mathrm{N}_{2}$ with total flow rate of $20 \mathrm{~mL} / \mathrm{min}$. as described in previous report [15]. 1-Butanol was pumped continuously into a preheated $\left(450{ }^{\circ} \mathrm{C}\right)$ stainless steel reactor which $\mathrm{Mn} / \mathrm{AC}$ catalyst was placed into the middle of the reactor. The reaction product was collected and distilled at $200^{\circ} \mathrm{C}\left(15.8^{\circ} \mathrm{C}\right.$ below DBB boiling point). The remaining liquid in the distilling flask (residue) was analyzed by GC-MS and HSQC NMR using chloroform-d solvent to confirm the existence of DBB in the product and determine its purity.
The $\bar{V}^{E}$ of DBB-DF mixture was determined by density test of a series of DBB-DF mixtures at different DBB mole fraction. The molecular weight of DF $(M)$ was estimated by Riazi-Daubert method [16] as shown in Eq. (1).

$$
\begin{gathered}
M=223.56 \times \\
{\left[v_{37.8}^{(-1.2435+1.1228 S)} v_{98.9}^{(3.4758-3.038 S)}\right] S^{-0.6665}}
\end{gathered}
$$

The three input parameters involved in Eq. (1) are kinematic viscosities (in $\mathrm{mm}^{2} / \mathrm{s}$ ) at $37.8^{\circ} \mathrm{C}$ and $98.9^{\circ} \mathrm{C}$ as shown by $v_{37.8}$ and $v_{98.9}$ and specific gravity, $S$, at $15.56^{\circ} \mathrm{C}$. The $\bar{V}^{E}$ of the system was determined by Eq. (2) $[17]:$

$$
\bar{V}^{E}=\sum_{i=1}^{n} x_{i} M_{i}\left(1 / \rho-1 / \rho_{i}\right)
$$

where, $n$ is components number, $x_{i}$ is mole fraction of component $i$ in the mixture, $M_{i}$ is molecular weight of component $i, \rho$ is density of the mixture, and $\rho_{i}$ is density of component $i$.

Homogeneity and phase stability of the DBB-DF mixtures were determined by density test. The homogeneity of the mixture is indicated by no significant differences in densities of three spot samples which were taken after the mixture settled for 5 minutes at different liquid depth (upper, middle, and lower spot samples) at ambient temperature. Phase stability of the mixture is indicated by no significant differences in densities of three spot samples which were taken after the mixture settled for 0.5 to 24 hours at ambient temperature. The temperature effect on phase stability of the mixture was determined by visual observation after the mixture was subjected to cooling until reach its pour point temperature.

The suitability of DBB as a blending component of DF was determined by mixing DBB with DF to give $5 \%$ by volume of $\mathrm{DBB}$ in the mixture. The mixture was then characterized to determine its cetane number, lubricity, pour point, heat of combustion, and viscosity according to ASTM standard methods. The same characterization was also conducted for $10 \%$ by volume of DBB in DF, net DF, and net DBB. 


\subsection{Detection Method}

Molecular structure and purity of DBB were confirmed by GC-MS Shimadzu QP2010S and HSQC NMR JNM-ECZ500R/S1. DF, DBB and their mixtures were analyzed for their density by Anton Paar DMA4500, cetane number by CFR (cooperative fuel research) F-5 Engine, lubricity by HFRR (high frequency reciprocating rig) PCS Instruments, cold flow quality by cloud and pour point app. Koehler KLA-3-TS/2, heat of combustion by Parr 6300 Automatic Isoperibol Calorimeter, and kinematic viscosity by Automated Viscosity Analyzer Herzog HVM 472. The hydrocarbon types of DF were determined by Fluorescent Indicator Adsorption method. The cetane number of the net DBB was calculated using the cetane number of the mixture data, by assuming a linear blending rule, according to Eq. (3).

$$
C N_{D B B}=\left(C N_{\text {mix }}-\left(C N_{D F} \times f_{D F}\right)\right) / f_{D B B}
$$

where $C N_{D B B}$ is cetane number of $\mathrm{DBB}, C N_{D F}$ is cetane number of DF, $C N_{m i x}$ is cetane number of DBB-DF mixture, $f_{D B B}$ is volume fraction of $\mathrm{DBB}$ in the mixture, and $f_{D F}$ is volume fraction of $\mathrm{DF}$ in the mixture.

\section{Results and Discussion}

\subsection{The Molecular Structure and Purity of DBB}

The GC-MS analysis of the residue sample indicated the purity of DBB was $87.73 \%$. Some small peaks which also appear indicated product impurities. The HSQC NMR spectrum of the residue sample is shown in Fig. 2. The number of proton and carbon were confirmed by ${ }^{1} \mathrm{H}$ NMR and ${ }^{13} \mathrm{C}$ NMR spectrum integrations as has been reported in Ref. [15]. The correlation of $0.88 \mathrm{ppm}\left(\mathrm{t}, \mathrm{J}=7.33 \mathrm{~Hz}, 9 \mathrm{H}, 4-\mathrm{CH}_{3}\right.$ and 4' $\left.-\mathrm{CH}_{3} \times 2\right)$ with $13.97 \mathrm{ppm}\left(\mathrm{s}, 2 \mathrm{C}, 4^{\prime}-\mathrm{CH}_{3} \times 2\right)$ and $14.03\left(\mathrm{~s}, 1 \mathrm{C}, 4-\mathrm{CH}_{3}\right)$ indicates there are three methyl groups in the compound structure. The correlation of 1.27-1.39 ppm (m, $6 \mathrm{H}, 3-\mathrm{CH}_{2}$ and 3 ' $\left.-\mathrm{CH}_{2} \times 2\right)$ with $18.19 \mathrm{ppm}\left(\mathrm{s}, 1 \mathrm{C}, 3-\mathrm{CH}_{2}\right)$ and $19.51 \mathrm{ppm}(\mathrm{s}, 2 \mathrm{C}$, 3 ' $-\mathrm{CH}_{2} \times 2$ ) indicates there are three methylene groups in the compound structure. Another three methylene



Fig. 2 HSQC NMR spectrum of the residue sample obtained from distillation of 1-butanol decomposition (on Mn/AC catalyst at $450{ }^{\circ} \mathrm{C}$ ) product. 
groups are indicated by correlation of $1.46-1.58 \mathrm{ppm}$ (m, $6 \mathrm{H}, 2^{\prime}-\mathrm{CH}_{2} \times 2$ and 2- $\left.\mathrm{CH}_{2}\right)$ with $32.06 \mathrm{ppm}(\mathrm{s}, 2 \mathrm{C}$, 2 ' $\left.-\mathrm{CH}_{2} \times 2\right)$ and $35.62 \mathrm{ppm}\left(\mathrm{s}, 1 \mathrm{C}, 2-\mathrm{CH}_{2}\right)$. There are two alkoxy methylene groups in the compound structure as indicated by correlation of $3.36 \mathrm{ppm}(\mathrm{dt}, \mathrm{J}$ $\left.=9.39,6.75 \mathrm{~Hz}, 2 \mathrm{H}, 1^{\prime}-\mathrm{CH}_{\mathrm{a}}\right)$ and $3.53 \mathrm{ppm}(\mathrm{dt}, \mathrm{J}=$ 9.39, $6.75 \mathrm{~Hz}, 2 \mathrm{H}, 1^{\prime}-\mathrm{CH}_{\mathrm{b}}$ ) with $65.14 \mathrm{ppm}(\mathrm{s}, 2 \mathrm{C}$, 1 ' $\left.-\mathrm{CH}_{2} \mathrm{O} \times 2\right)$. The correlation of $4.43 \mathrm{ppm}(\mathrm{t}, \mathrm{J}=5.72$ $\mathrm{Hz}, 1 \mathrm{H}, 1-\mathrm{CH})$ with 102.95 ppm (s, $1 \mathrm{C}, 1$-acetal-C) indicates there is an acetal methine group in the compound structure. The existence of acetal carbon at chemical shift of $102.95 \mathrm{ppm}$ was consistent with Silverstein et al. [18]. The similar result also has been reported by Kamizono et al. [19].

\subsection{Fuel Mixture Characteristics}

\subsubsection{Excess Molar Volume}

The $\bar{V}^{E}$ of the mixtures of DBB-DF shows positive $\bar{V}^{E}$ values over the whole concentration range (Fig. 3). It indicates the DBB addition has disturbed the weak interaction exist among hydrocarbon molecules of the $\mathrm{DF}$ and there are no specific interactions formed between DBB and DF molecules. This information has significant meaning when applied for process engineering, such as in storage tank or compartment capacity designs.

3.2.2 Homogeneity and Stability of the Mixture

The homogeneity of the mixture was determined by taking $5 \mathrm{~mL}$ of three spot samples after the mixture was stirred and settled for 5 minutes at ambient temperature. The terms and sampling points of spot samples are determined according to ASTM D4057. The liquid depth for sampling is taken to the nearest $5 \mathrm{~mL}$ of the $500 \mathrm{~mL}$ graduated cylinder scale. Each sample was subjected to density test and the results are shown in Table 1 . There are no significant density differences either in $5 \%$ or $10 \%$ by volume of the DBB-DF mixtures. It can be said that the addition of DBB into DF forms a homogeneous mixture.

Fig. 4 shows the settling time effect on phase stability of the mixture at ambient temperature. There are no significant differences on density values until the mixture settled for $24 \mathrm{~h}$, which indicates the mixture has a good phase stability at ambient temperature.

The effect of temperature on phase stability was determined by taking about $40 \mathrm{~mL}$ of the mixture into the pour point jar and cooled. The phase observations were made at interval of $3{ }^{\circ} \mathrm{C}$ lower. The result showed there was no phase separation observed under cooling condition until the mixture becomes solid. This is an important fuel property, especially when the fuel is stored and handled in cold weather.

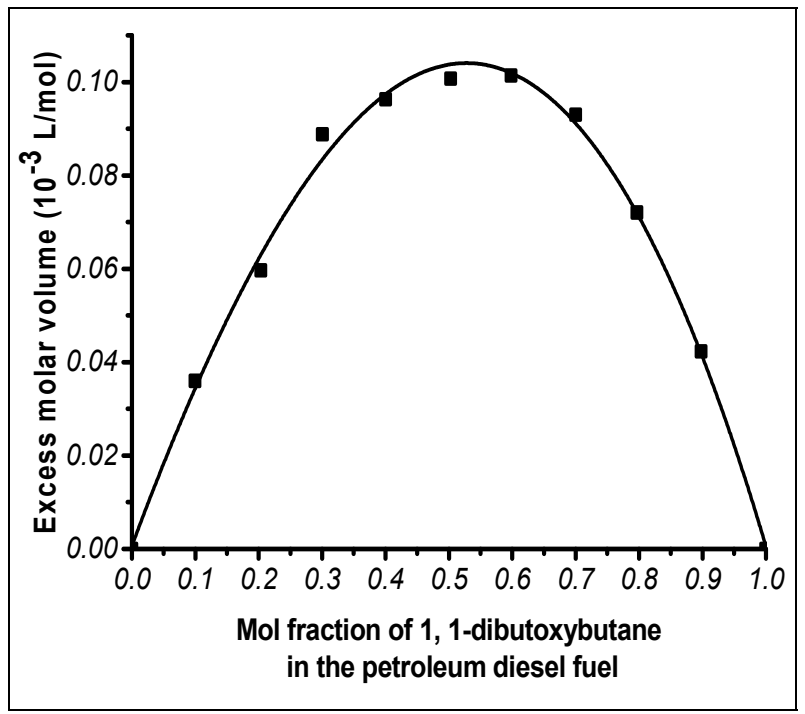

Fig. 3 Excess molar volume of the 1,1-dibutoxybutane petroleum diesel fuel mixture.

Table 1 The density test results of 1,1-dibutoxybutane petroleum diesel fuel mixtures after settled for 5 min at ambient temperature.

\begin{tabular}{lll}
\hline \multirow{2}{*}{ Spot sample type } & \multicolumn{2}{c}{ Density at $15^{\circ} \mathrm{C}\left(\mathrm{kg} / \mathrm{m}^{3}\right)$} \\
\cline { 2 - 3 } & $5 \%$ by volume of 1,1-dibutoxybutane in & $10 \%$ by volume of 1,1-dibutoxybutane in \\
& petroleum diesel fuel & 855.8 \\
Upper & 856.3 & 855.8 \\
Middle & 856.4 & 855.8 \\
Lower & 856.4 & petroum diesel fuel \\
\hline
\end{tabular}




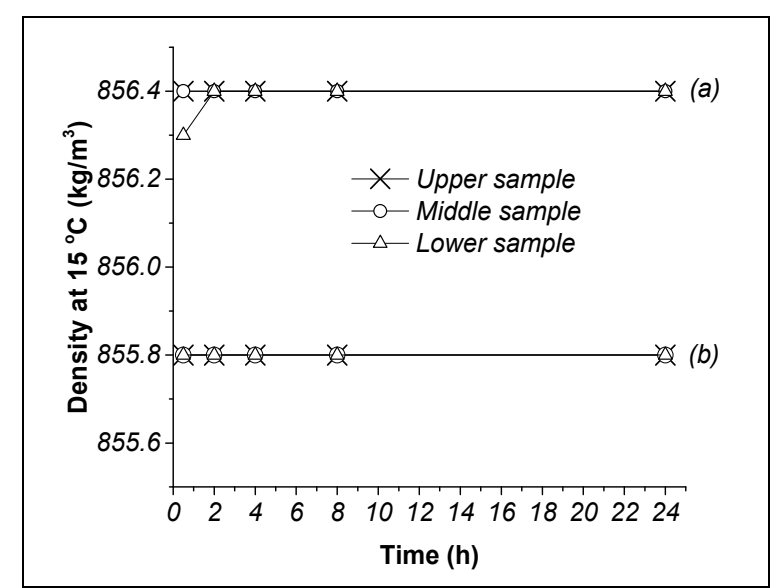

Fig. 4 Effect of settling time on phase stability of 1,1-dibutoxybutane petroleum diesel fuel mixture at ambient temperature: (a) $5 \%$ by volume of 1,1-dibutoxybutane in petroleum diesel fuel; (b) $10 \%$ by volume of 1,1-dibutoxybutane in petroleum diesel fuel.

\subsubsection{Fuel Ignition Quality}

The net DF, DBB-DF mixtures, and net DBB were analyzed according to ASTM standard methods and the results are shown in Table 2 .

Fuel ignition quality of diesel fuel is commonly quantified in terms of cetane number, which is a measure of the delay between injection and start of combustion. In combustion reaction, hydrogen abstraction is the rate-limiting steps and the energy barrier for these $\mathrm{H}$-abstractions will be proportional to the strength of the relevant $\mathrm{C}-\mathrm{H}$ bonds in the fuel molecule and the abstraction will occur fastest where the $\mathrm{C}-\mathrm{H}$ bonds are weakest [20]. The tertiary $\mathrm{C}-\mathrm{H}$ bonds adjacent to either an ether linkage or a carboxyl group is the weakest type of C-H bonds compared with secondary $\mathrm{C}-\mathrm{H}$ bonds adjacent to an ether linkage [20]. The DBB has one tertiary $\mathrm{C}-\mathrm{H}$ bonds adjacent to two ethers linkage (see Fig. 1), so the DBB more pronounced toward $\mathrm{H}$-abstraction to start the preignition, and thus it has high cetane number, i.e. 105 [13]. Table 2 shows that the cetane number increases as DBB proportion in the mixture increased.

Base on cetane number data of $10 \%$ by volume of DBB in the mixture (Table 2), by using Eq. (3) the calculated cetane number of the net DBB is 91.9. This calculated cetane number is lower than the DBB cetane number value as reported by Silva et al. [13]. This may be due to the effect of DBB purity and the composition of hydrocarbon types in the DF.

\subsubsection{Lubricity}

Table 2 shows that the lubricity of DBB fuel mixture slightly increases as DBB proportion in the mixture increased. It was shown by WSD (wear scar diameter) decreasing value. The highest WSD decreasing value is obtained from $10 \%$ DBB in the mixture. The lubricity is an important property of fuels which can minimize engine heat and wear. It is largely provided by trace levels of naturally occurring polar compounds which form a protective layer on the metal surface. The DBB has two ether structures in its molecule, so DBB is more polar compared with hydrocarbon in DF. But ether structure only contributes small lubricity [4]. For oxygenates the order of enhancing lubricity is $\mathrm{COOH}>$ $\mathrm{CHO}>\mathrm{OH}>\mathrm{COOCH}_{3}>\mathrm{C}=\mathrm{O}>\mathrm{C}-\mathrm{O}-\mathrm{C}$ [4].

\subsubsection{Cold Flow Quality}

In this report, cold flow quality is expressed as pour point. Under cooling conditions, highly unsymmetrical compounds crystallize slower than unsubstituted and symmetrically substituted compounds [21]. Continued cooling results more crystallized compounds in the system which could prevent the remaining liquid phase from flowing [22]. The DBB, with its branched-chain structure, has low pour point, below $-90^{\circ} \mathrm{C}$ (Table 2). However, the addition of DBB up to $10 \%$ by volume into DF cannot lower the pour point of the net DF $\left(9^{\circ} \mathrm{C}\right)$ (Table 2). It may be due to the molecular size of DBB which smaller compared to DF and the symmetrical geometry of DBB. The symmetrical structure can accommodate high London force between each molecule and its neighbors to become solid under cooling condition [22].

\subsubsection{Heat of Combustion}

The heat of combustion provides a knowledge of the amount of energy obtainable from a given fuel for the performance of useful work or power. Consequently, a reduction in the heat of combustion is accompanied by an increase in fuel consumption with corresponding 
Table 2 Characteristic of the net petroleum diesel fuel, 1,1-dibutoxybutane petroleum diesel fuel mixtures, and net 1,1-dibutoxybutane.

\begin{tabular}{|c|c|c|c|c|c|c|c|}
\hline \multirow[t]{2}{*}{ No. } & \multirow{2}{*}{ Properties } & \multirow{2}{*}{$\begin{array}{l}\text { ASTM } \\
\text { methods }\end{array}$} & \multirow{2}{*}{$\begin{array}{l}\text { Diesel fuel } \\
\text { specification }^{\text {a }} \\
\text { limit }^{\mathrm{a}}\end{array}$} & \multicolumn{4}{|c|}{$\begin{array}{l}\text { 1,1-Dibutoxybutane in the mixture with petroleum } \\
\text { diesel fuel (\% by volume) }\end{array}$} \\
\hline & & & & 0 & 5 & 10 & 100 \\
\hline 1 & Density at $15^{\circ} \mathrm{C}\left(\mathrm{kg} / \mathrm{m}^{3}\right)$ & D4052 & $815-870$ & 856.9 & 856.4 & 855.8 & 844.9 \\
\hline \multirow[t]{4}{*}{2} & $\begin{array}{l}\text { Hydrocarbon types by fluorescent } \\
\text { indicator adsorption }\end{array}$ & D1319 & & & & & \\
\hline & Aromatics $(\%)$ & & $-\mathrm{b}$ & 29.1 & $-{ }^{c}$ & $-c$ & $-^{c}$ \\
\hline & Olefins $(\%)$ & & $-b$ & 4.0 & $-{ }^{c}$ & $-\mathrm{c}$ & $-c^{c}$ \\
\hline & Saturates $(\%)$ & & $-b$ & 66.9 & $-{ }^{c}$ & $-{ }^{c}$ & $-^{c}$ \\
\hline 2 & Cetane number & D613 & Min. 48 & 51.9 & 53.7 & 55.9 & $105[13]$ \\
\hline 3 & $\begin{array}{l}\text { Lubricity (HFRR wear scar dia. @ } 60 \\
\left.{ }^{\circ} \mathrm{C}\right) \text { (micron) }\end{array}$ & D6079 & Max. 460 & 338 & 332 & 330 & 330 \\
\hline 4 & Pour point $\left({ }^{\circ} \mathrm{C}\right)$ & D97 & Max. 18 & 9 & 9 & 9 & $<-90$ \\
\hline 5 & Gross heat of combustion (MJ $/ \mathrm{kg})$ & D240 & $-\mathrm{b}$ & 42.786 & 41.587 & 40.127 & 36.946 \\
\hline 6 & Kinematic viscosity at $40^{\circ} \mathrm{C}\left(\mathrm{mm}^{2} / \mathrm{s}\right)$ & D445 & $2.0-5.0$ & 3.4718 & 3.3121 & 3.1342 & 1.5157 \\
\hline
\end{tabular}

a. According to Directorate General of Oil and Gas-Indonesia regulation, No.: $3675 \mathrm{~K} / 24 / \mathrm{DJM} / 2006$.

b. Not specified.

c. Not determined.

loss of range. The addition of DBB into DF has decreased the heat of combustion of the fuel mixture, and more pronounce when proportion of $\mathrm{DBB}$ in the mixture increased (Table 2). DBB consists of $15.8 \%$ oxygen and the oxygen content influences the stoichiometric air/fuel ratio. The presence of oxygen leans out the fuel mixture, which means more fuel must be added to compensate the air/fuel ratio when burning DBB.

\subsubsection{Viscosity}

Viscosity of the net DF is higher than DBB, and the viscosity of their mixtures tends to decrease when DBB proportion in the mixture increased (Table 2). Viscosity measures resistance to flow. It relates directly to intermolecular interactions, because such forces tend to resist the movement of one molecule relative to another. With larger, longer chain, and higher branched chain hydrocarbon molecules, opportunity for intermolecular entanglement and London-force interactions increase. The heteroatomic compounds have higher viscosities than the related hydrocarbons, indicating an effect of the permanent dipole moment on intermolecular interactions [22]. The DBB molecule has branched-chains and oxygen atoms. However, its branched-chains are relative short, so it has less opportunities for molecular entanglements among them or with DF molecules and the oxygen atoms are relative hindered so effect of the permanent dipole moment on intermolecular interactions is small. As results, the viscosity of DBB is lower $\left(1.5157 \mathrm{~mm}^{2} / \mathrm{s}\right.$ at $\left.40{ }^{\circ} \mathrm{C}\right)$ compared to 1-butanol as its feedstock $\left(4.1482 \mathrm{~mm}^{2} / \mathrm{s}\right)$ [23] and the kinematic viscosity of the mixture decreases as the DBB proportion in the mixture increased. The low viscosity of DBB can be used in lowering DF-biodiesel mixture which tends to have high viscosity.

\section{Conclusions}

The addition of DBB into DF shows positive $\bar{V}^{E}$ values over the whole concentration range. The DBB-DF mixture forms a homogeneous mixture and it has a good phase stability. The cetane number and lubricity of $\mathrm{DBB}$ could improve the ignition quality and engine live. The addition of DBB into DF does not decrease the cold flow quality of the mixture. The viscosity of $\mathrm{DBB}$ is lower than $\mathrm{DF}$, however the viscosity of the mixture still conformed with $\mathrm{DF}$ specification up to $10 \%$ by volume DBB addition. The energy content by weight basis of DBB is slight lower than DF, so it will be more fuel needed when DBB is used as DF blending component. 


\section{References}

[1] Wijaya, K., Syoufian, A., and Ariantika, S. D. 2014. "Hydrocracking of Used Cooking into Biofuel Catalyzed by Nickel-Bentonite." Asian Journal of Chemistry 26 (13): 3785-9.

[2] Imdadul, H. K., Masjuki, H. H., Kalam, M. A., Zulkifli, N. W. M., Rashed, M. M., Rashedul, H. K., Monirul, I. M., and Mosarof, M. H. 2015. "A Comprehensive Review on the Assessment of Fuel Additive Effects on Combustion Behavior in CI Engine Fuelled with Diesel Biodiesel Blends." RSC Advances 5 (83): 67541-67.

[3] Agirre, I., Güemez, M. B., Ugarte, A., Requies, J., Barrio, V. L., Cambra, J. F., and Arias, P. L. 2013. "Glycerol Acetals as Diesel Additives: Kinetic Study of the Reaction between Glycerol and Acetaldehyde." Fuel Processing Technology 116 (December): 182-8.

[4] Knothe, G., and Steidley, K. R. 2005. "Lubricity of Components of Biodiesel and Petrodiesel. The Origin of Biodiesel Lubricity." Energy and Fuels 19 (3): 1192-200.

[5] Waller, F. J., Weist Jr., E. L., Brown, D. M., and Tijm, P. J. A. 1999. Diesel fuel composition comprising dialkoxy alkanes for increased cetane number. US Patent No. $5,858,030$.

[6] Hille, M., Weinelt, F., Wittkus, H., and Reimann, W. 2000. Environmentally friendly diesel fuel. US Patent No. 6013114.

[7] Nord, K. E., and Haupt, D. 2005. "Reducing the Emission of Particles from a Diesel Engine by Adding an Oxygenate to the Fuel." Environmental Science and Technology 39 (16): 6260-5.

[8] Frusteri, F., Spadaro, L., Beatrice, C., and Guido, C. 2007. "Oxygenated Additives Production for Diesel Engine Emission Improvement." Chemical Engineering Journal 134 (1-3): 239-45.

[9] Rahaman, M., Graça, N. S., Pereira, C. S. M., and Rodrigues, A. E. 2015. "Thermodynamic and Kinetic Studies for Synthesis of the Acetal (1,1-Diethoxybutane) Catalyzed by Amberlyst 47 Ion-Exchange Resin." Chemical Engineering Journal 264 (March): 258-67.

[10] Szymanski, G., Rychlicki, G., and Terzyk, A. P. 1994. "Catalytic Conversion of Ethanol on Carbon Catalysts." Carbon 32 (2): 265-71.

[11] Chao, L., Yong, L., Zhongmin, L., Derek, M. F., Lina, L., Shiping, L., and Hui, Z. 2013. Method for preparing acetaldehyde and co-producing acetal by using ethanol.
China Patent No. CN 103130625 A.

[12] Germanaud, L., Maldonado, P., Bourdauducq, P., and Couturier, J. L. 2000. Fuel Composition for diesel engines containing oxygenated compounds. US Patent No. 6113661.

[13] Silva, V. M. T. M., Pereira, C. S. M., Rodrigues, A. E., Verevkin, S. V., Emel'yanenko, V. N., Garist, I. V., and Gmehling, J. 2012. "Experimental and Theoretical Study of Chemical Equilibria in the Reactive Systems of Acetals Synthesis." Industrial and Engineering Chemistry Research 51 (39): 12723-9.

[14] Green, E. M. 2011. "Fermentative Production of Butanol-the Industrial Perspective." Current Opinion in Biotechnology 22 (3): 337-43.

[15] Yoeswono, Triyono, and Falah, I. I. 2016. "Catalytic Activity of $\mathrm{Mn} / \mathrm{AC}$ Catalyst on Direct Synthesis of 1,1-Dibutoxybutane from 1-Butanol.” In AIP Conference Proceedings, 1755: 080008-1-080008-7.

[16] Riazi, M. R. 2005. Characterization and Properties of Petroleum Fractions (ASTM Manual Series: MNL50), 1st ed. West Conshohocken: ASTM.

[17] Djordjevic, B., Radovic, I., Kijevcanin, M., Tasic, A., and Serbanovic, S. 2009. "Molecular Interaction Studies of the Volumetric Behavior of Binary Liquid Mixtures Containing Alcohols." Journal of the Serbian Chemical Society 74 (5): 477-91.

[18] Silverstein, R. M., Webster, F. X., and Kiemle, D. J. 2005. Spectrometric Identification of Organic Compounds, 7th ed. Hoboken: John Wiley \& Sons, Inc.

[19] Kamizono, T., Ohtsuka, A., Hashimoto, F., and Hayashi, K. 2013. "Dibutoxybutane Suppresses Protein Degradation and Promotes Growth in Cultured Chicken Muscle Cells." Japan Poultry Science Association 50 (1): 37-43.

[20] Yanowitz, J., Ratcliff, M. A., McCormick, R. L., Taylor, J. D., and Murphy, M. J. 2014. "Compendium of Experimental Cetane Numbers." National Renewable Energy Laboratory. Accesed June 4, 2015. http://www.nrel.gov/publications.

[21] Speight, J. G. 2007. The Chemistry and Technology of Petroleum, 4th ed. Boca Raton: Taylor and Francis Group.

[22] Schobert, H. 2013. Chemistry of Fossil Fuels and Biofuels. Cambridge: Cambridge University Press.

[23] Muzikova, Z., SImacek, P., Pospisil, M., and Sebor, G. 2014. "Density, Viscosity and Water Phase Stability of 1-Butanol-Gasoline Blends.” Journal of Fuels (January): 1-7. http://dx.doi.org/10.1155/2014/459287. 